\title{
RAUAAJA ALGUS JA VILJAKASVATUSE KUJUNEMINE PŌHILISEKS ELATUSVIISIKS KIRDE-EESTI ALAL
}

\author{
M. SCHMIEDEHELM, \\ ajalooteaduste kandidaat
}

Kirde-Eesti rannikuala pakub oma mälestusmärkide rohkuse poolest Eesti NSV territooriumi piires kõige paremaid võimalusi ühiskondlikmajandusliku arengu jälgimiseks tuhandeaastases ajavahemikus umbes a, 500 enne meie ajaarvamist kuni a. $500 \mathrm{~m}$. a. j. Selle aja jooksul toimus suure tähtsusega muudatus tootmises Baltimail asuvail hõimudel: üleminek majanduselt, milles teatud määral juhtivaks oli karjakasvatus, majandusele, mille aluseks oli viljakasvatus. Uhtlasi teostus seega olulise tähtsusega edusamm ühiskondliku tööjaotuse arengus.

Tuleb märkida, et selle perioodi esimesele poolele on seni pööratud vähe tähelepanu, sest varemal-ajal piirdus arheoloogia peamiselt m. a. II-VI sajandisse kuuluvate suurte leiduderikaste tarandkalmete uurimisega. Balti-saksa uurijad, kes läinud sajandi teisel poolel ja käesoleva sajandi algul peamiselt uurisidki neid kalmeid praegusel Eesti NSV ja Läti NSV territooriumil, olid huvitatud ainult etnilisest probleemist, otsides arheoloogilistest materjalidest tuge oma tendentslikule väitele, et Baltimaad olevat põline germaanlaste ala. Kodanliku Eesti uurijad omistasid need kalmed küll eestlaste eelkäijatele, kuid lähtudes oma kosmopoliitilistest, ebateaduslikkudest seisukohtadest, nägid nende arengut edasiviivat jõudu ainult väljaspoolt, eeskätt läänest tulevates "kultuurimõjudes", nagu seda on teinud ka käesoleva kirjutise autor oma kodanlikul ajal ilmunud töödes. Sisemist tegurit, tootlikke jõude ja nende kasvu kui ajaloolist arenemist tõeliselt määravat põhjust ignoreeriti nii saksa kui ka kodanliku aja eesti arheoloogide pooit. Käesolev kirjutis ongi katseks näidata tootmise arengut ja vastavaid muudatusi ühiskondlikes vahekordades ning pealisehituslikkudes nähtustes meie ajaarvamise alguse ümber Kirde-Eesti alal.

Tuleb märkida, et meil kasutada olev arheoloogiline ainestik selle perioodi kohta on vaatamata oma rohkusele alles puudulik. Rääkimata asjaolust, et vanemad kaevamised oma tehnika poolest ei vasta kaasaegse nõukogude arheoloogia nõudeile, on materjal väga ühekülgne ka seetõttu, et see pärineb peaaegu ainult kalmetest. Alles nõukogude perioodil avanes võimalus linnuste uurimiseks. 1949.-1950, aastal kaevati Kiviõli rajooni Koila linnust (Viru-Nigula ligidal), kusjuures ilmnes, et selle alumine kiht kuulub (seal leitud tekstiilkeraamika järgi otsustades) aega meie ajaarvamise alguse ümber. Kaevamised näitasid aga ühtlasi, et seda linnust pole kuigi suurel määral kasutatud elamiseks, millest tuleb järeldada, et sel ajal elati selles piirkonnas juba lahtistes 
asulates, kasutades linnust peamiselt kaitse otstarbel sugukondade- või hõimudevaheliste kokkupõrgete puhul. Sama tuleb öelda ka III-IV sajandisse kuuluva Kloodi linnuse kohta (Rakvere ligidal), kus toimetati kaevamisi 1951. ja 1952. a.

Varaseima rauaaja tüüpilisteks kalmeteks Eesti NSV territooriumil on nn. kivikirstkalmed, s. o. ümarikud kuhelikukujulised kivikangrud, mis asuvad harilikult rühmiti mitmekaupa koos. Surnud on neisse maetud kas põletamata või põletatult paeplaatidest ehitatud kirstudesse, milliseid samas kangrus esineb enamasti mitu. Panuste poolest on kivikirstkalmed tavaliselt äärmiselt vaesed, mistõttu nende dateerimine oli kauemat aega lahtine. Nüüd on siiski kindlaks tehtud, et neid hakati ehitama pronksiaja lõpul, s. o. vähe enne I aastatuhande keskpaika enne meie ajaarvamist, kuna nende päristarvitamise ajaks on viimased sajandid enne meie ajaarvamist ja osalt ka veel meie ajaarvamise esimene aastasada.

Seni uuritud kivikirstkalmetest on kõige paremini dateeritud 1925. a. kaevatud kalme Jäbaral, umbes $8 \mathrm{~km}$ Lüganusest kirde poole ${ }^{1}$.

Seal leidub pikk rida kalmeid, üldulatusega üle $200 \mathrm{~m}$, mis asetsevad piki loomulikku kruusaseljakut mere poole laskuva lavatasandiku ääres. Olgugi et neist on seni läbi kaevatud vaid väike osa, on võidud kindlaks teha, et nad kuuluvad peamiselt meie ajaarvamise III-V sajandisse. Kuid on ka varasemaid kalmeid. Uks neist, kalme A (joon. 1) oli väike kangur, 8-9 m läbimõõduga, mille keskel leidus tugev kivikirst paksudest, serviti asetatud plaatidest. Selles olnud luustikust oli säilinud ainult veidi luupuru. See oli kõnealuses kalmes tõenäoliselt kõige vanem matus, mida aga kahjuks panuste puudusel ei saa täpsemalt dateerida. Selle kirstu kõrval, kalme ääre poole oli veel teisi, nähtavasti natuke hilisemaid matuseid, nii kivikirstudes kui ka ilma kirstudeta. Neist oli eriti huvitav matus I (joon. 2), mis sisaldas selle aja kohta haruldaselt palju leide: pronksist käevõru ja kaelavõru (joon. $3: 1,2$ ), suure raudnoa (joon. 3:3) ja väikese noakatkendi. Teisel, kõrval oleval luustikul oli kaasas suure raudeseme katkend, arvatavasti umbes samasugusest noast nagu eelmisel. Mõlemad surnud olid maetud kivikirstudesse, kuid neer kirstud olid hoopis õhematest, korratumalt asetatud plaatidest kui kalme keskmine kirst. Kalme äärest oli põllu kündmisel veel enne kaevamist leitud katkendiline rauast mõõga- või põuenoa sarnane ese ja massiivne rauast käevõru.

Ulalnimetatud kaelavõrule (joon. 3:2) ei ole teada vasteid ei Eesti NSV territooriumilt ega ka lähematelt naaberaladelt. Enam-vähem samaaegseks võib lugeda kujult veidi erinevat kaelavõru, mis on leitud 1895. a. S. K. Bogojavlenski poolt kivikirstkalmest Kaunispäält Sõrve poolsaarel,

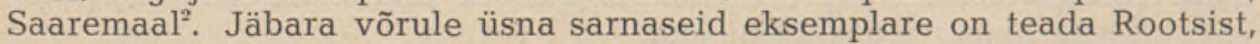
kus neid dateeritakse I aastatuhande keskpaika enne meie ajaarvamist. Kuigi nende võrude dateerimine vastavate leidude vähearvulisuse tõttu ei ole võib-olla päris täpne, näitab ometi Jäbara leid, milles võru kõrval oli suur raudnuga, et umbes I aastatuhande keskpaigu oli meil raud juba tuntud, Nii varajane rauatarvitamine meie põhjapoolsetel aladel paistis alles hiljuti võimatuna, kuid 1946. a. M. E. Fossi poolt Kostroma oblastis Galitši järve kaldal avastatud rauasulatamise koht näitab, et algelist rauatootmist kohalikest maakidest tunti NSV Liidu metsavöötme

1 Kõik käesolevas kirjutises nimetatud kaevamisaruanded säilitatakse Eesti NSV Teaduste Akadeemia Ajaloo Instituudi (AI) arheoloogiasektoris.

2 Труды Московского предварительного комитета X археологического съезда в г. Риге. II, M., 1896, lk. 23-24. 


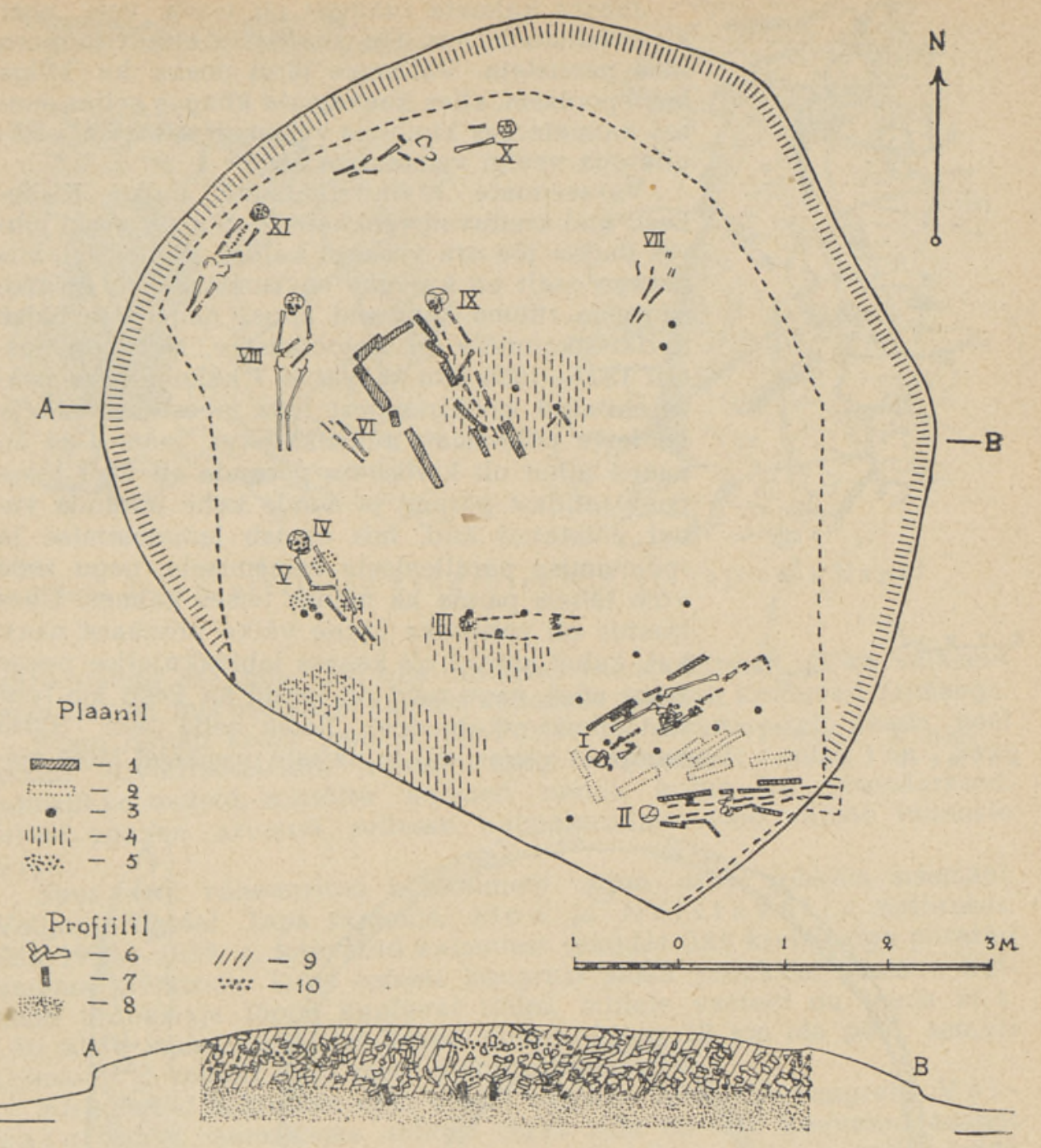

Joon. 1. Kiviõli rajooni Jäbara kalme A. Märgid põhiplaanil: 1. Kivikirstu seinaplaat. 2. Sama, skemaatiliselt. 3. Leid. 4. Põletamata luid suuremal hulgal. 5. Põlenud luude pesa. Mărrgid lõikel: 6. Paekive. 7. Kivikirstu seinaplaat. 8. Aluspõhja kruus. 9. Kultuurkiht. 10. Põletamata luid.

alal juba VIII-VII sajandil e.m. a. ${ }^{3} \quad$ Kuigi raud võis seega olla tuntud ka Eesti NSV alal juba I aastatuhande keskpaigu enne meie ajaarvamist, oli selle primitiivne tootmine alles niivõrd väheproduktiivne, et veeI kaua (vähemalt ka veel I sajandil m. a. j.) tarvitati igapäevase töö jaoks endiselt riistu luust, sarvest ja kivist, millele osutavad leiud selle aja linnus-asulatest, nagu Asvast Saaremaal, Klangukalnsilt Riia lähedal ja nn. Djakovo tüüpi linnuselt Volga-Okaa alal.

3 М. Е. Фосс, Результаты Галичской экспедиции 1946 г. Краткие сообщения о докладах и полевых исследованиях Института истории материальной культуры, ХХ. М.-Л., 1948, lk. $58-65$.

М. Е. Фосс, Итоги Галичской экспедицни. Краткие сообщения о докладах и полевых исследованнях Института истории матернальной культуры, XXVI. М.-Л., 1949, lk. $38-39$. 


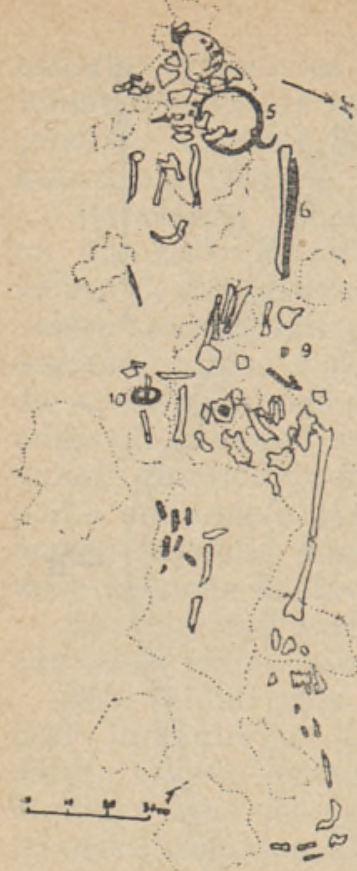

Joon. 2. J äbara a joon. 2 . J äb a r a
Jäbara kalmete rühmast on teada veel paar kivikirsthauda, mis aga sisaldasid ainult luupuru ilma panusteta. Välimuse järgi peaks ka kõige läänepoolsem, alles kaevamata küngas selles suures kalmetereas kuuluma vähemalt samasse, võibolla aga veelgi vanemasse aega.

-Varaseimate kivikirstkalmete hulka KirdeEesti alal kuuluvad veel kalmed $\mathrm{N}$ a p a veski juures Purtse jõe oru vasakul kaldal, loopealsel, mis praegu osalt on kuivaks karjamaaks. Siin leiame suurema rühma kangruid koos, nagu see üldse kivikirstkalmeile on iseloomustav. Neist on aastail 1927-1928 läbi kaevatud 7 kalmet. Maa peale ehitatud kivikirstudest leiti meeste, naiste ja ka laste põletamata luustikke (vt. joon. 4 ja 5); paaril juhul oli kivikirstu põranda all veel teine paeplaatidest põrand ja nende kahe põranda vahel põletatud luid, mis osutab laibamatmise ja -põletamise paralleelsele esinemisele, nagu seda võib tähele panna ka mõnes teises kalmes. Uhes kirstus oli panuseks lihtne väike pronksist naaskel, kahel surnul oli kaasas labidakujulise peaga luust nõel, nagu neid on leitud ka Eesti ala teistest kivikirstkalmetest. Peale selle leiti ühest kangrust väljaspool kivikirstu pronksist lame spi-
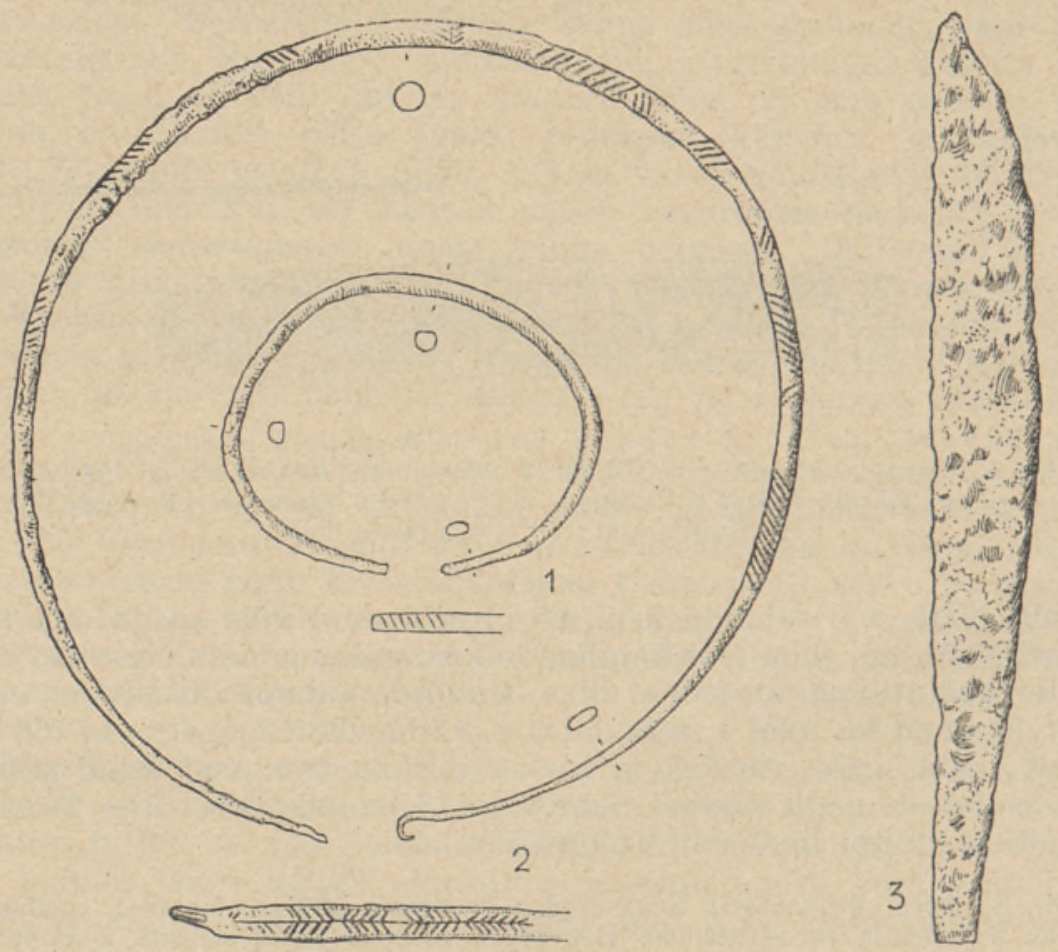

Joon, 3. Kaelavõru, käevõru ja nuga Jäbara kalme A luustiku I juurest (AI 2570:5, 10, 6). $1-2$ pronksist, umb. $1 / 2$ loomulikust suurusest; 3 rauast, umb. 1/3 loomulikust suurusest. 

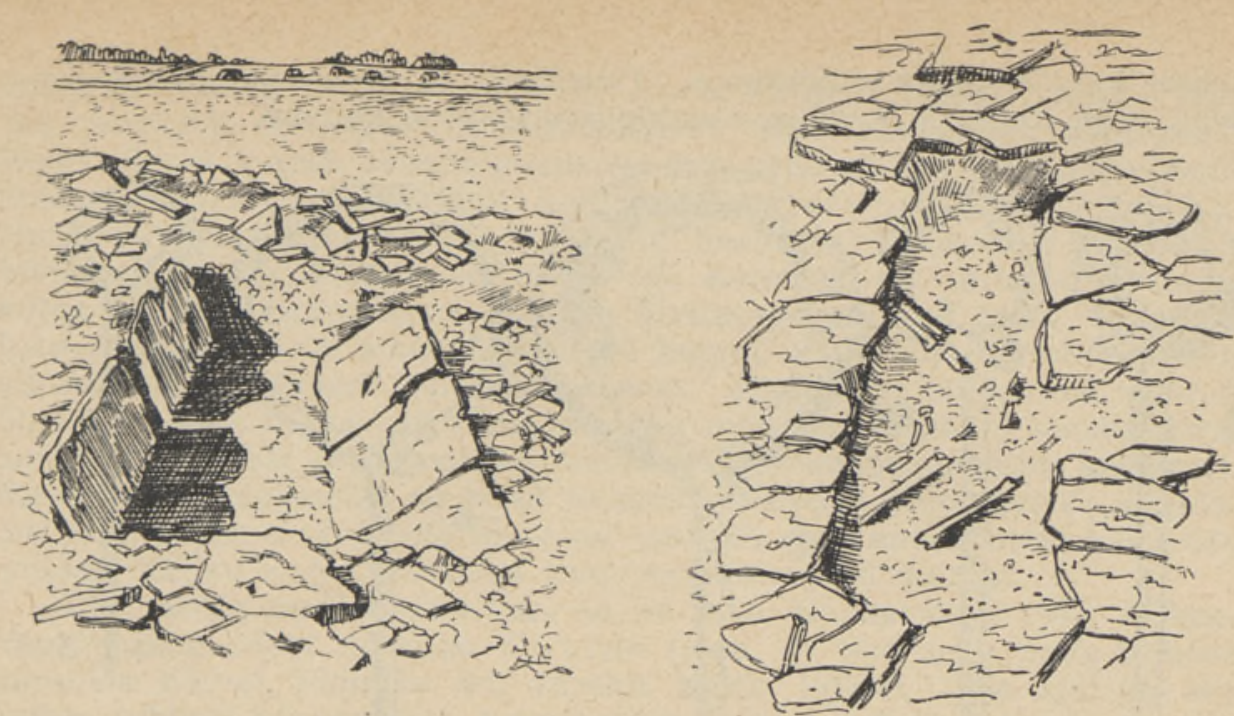

Joon. 4-5. Kivikirstud kangrutes Kiviõli rajoonis $\mathrm{Napal}$.

raalikujuline ese, mis võib olla oimuehe. Mõnes kirstus oli ka väikseid rauatükikesi, mis osutab, et kalmed vähemalt osaliselt kuuluvad rauaaega.

Nagu näitab kaart joon. 8, on Purtse jõe suudmealalt teada veel teisigi kivikirstkalmete rühmi, kuigi mõnedest neist on vaid juhuslikke teateid, mistõttu andmed nende kohta on ebamäärásed, teised aga on arvatud sellesse kalmeterühma vaid väliste tunnuste järgi.

Suur, seni väheuuritud kivikalmete rühm asub rohkem sisemaal, Valgejõe ligidal Tapa rajoonis, Moe ja $\mathrm{N}$ a is t e väl ja ümbruses. Siin 1909.-1910. a. kaevatud kalmetest sisaldas üks kiviringiga piiratud kangur kivikirstu, kuna teisest kangrust saadi pronksist pintseti katkend pronksiaja lõppu kuuluvat tüüpi, millele vasteid on teada $\mathrm{m}$. s. Läti alalt, suurest kääpast Rezne juures, Riiast $18 \mathrm{~km}$ ida pool, samuti Ojamaalt ja mujalt Balti mere ümbruskonnast.

Kirjeldatud kalmetele näib olevat samane rühm kivikangruid V a i v a r a ligidal mererannas, millest terve rida on läbi kaevatud aastail 1895-1897. Tolle aja puuduliku kaevamistehnika tõttu on raske öelda midagi kindlat nende sisemise struktuuri kohta, kuid vähemalt ühes neist leiti paeplaatidest kirst, milles oli põletamata luid. Teistesse olid surnud maetud samuti enamasti põletamata. Panuseid pole siit saadud peale mõne lihtsa savinõutüki, mille tõttu nende kangrute vanust ei saa täpselt määrata.

Ulalkäsitletud kalmetest on mõnevõrra noorem 1935. a. uuritud kangur Rakvere rajoonis K u u ra s. Selle ainus võrdlemisi halvasti säilinud kivikirst sisaldas põlenud luid ja panusena ühe rauast nn. karjasekeppnõela (joon. 6:1). See on rõngakujulise peaga nõel, millel rõngast moodustava traadi ots on keeratud väikeseks aasaks. Need nõelad olid tarvitusel riietekinnitamise abinõudena, kusjuures rõivast väljaulatuv์ nõela pea ja teraviku ots ühendati arvatavasti nööriga, et ära hoida nõela väljalibisemist rõivaist. Niisugusele nõelte tarvitamisviisile osutavad mõned naabermailt saadud leiud, kus on säilinud orgaanilisest ainest nööri jäänuseid. Kui hiljem, meie ajaarvamise II sajandil tuli tarvitusele sõlg, siis oli see kahtlemata teatud edusammuks, millega käis 
kaasas ka rõivastuse muutumine. Tehniliselt oli nende nõelte valmistamine väga lihtne ja algelise rauatöötlemisoskuse kohane.
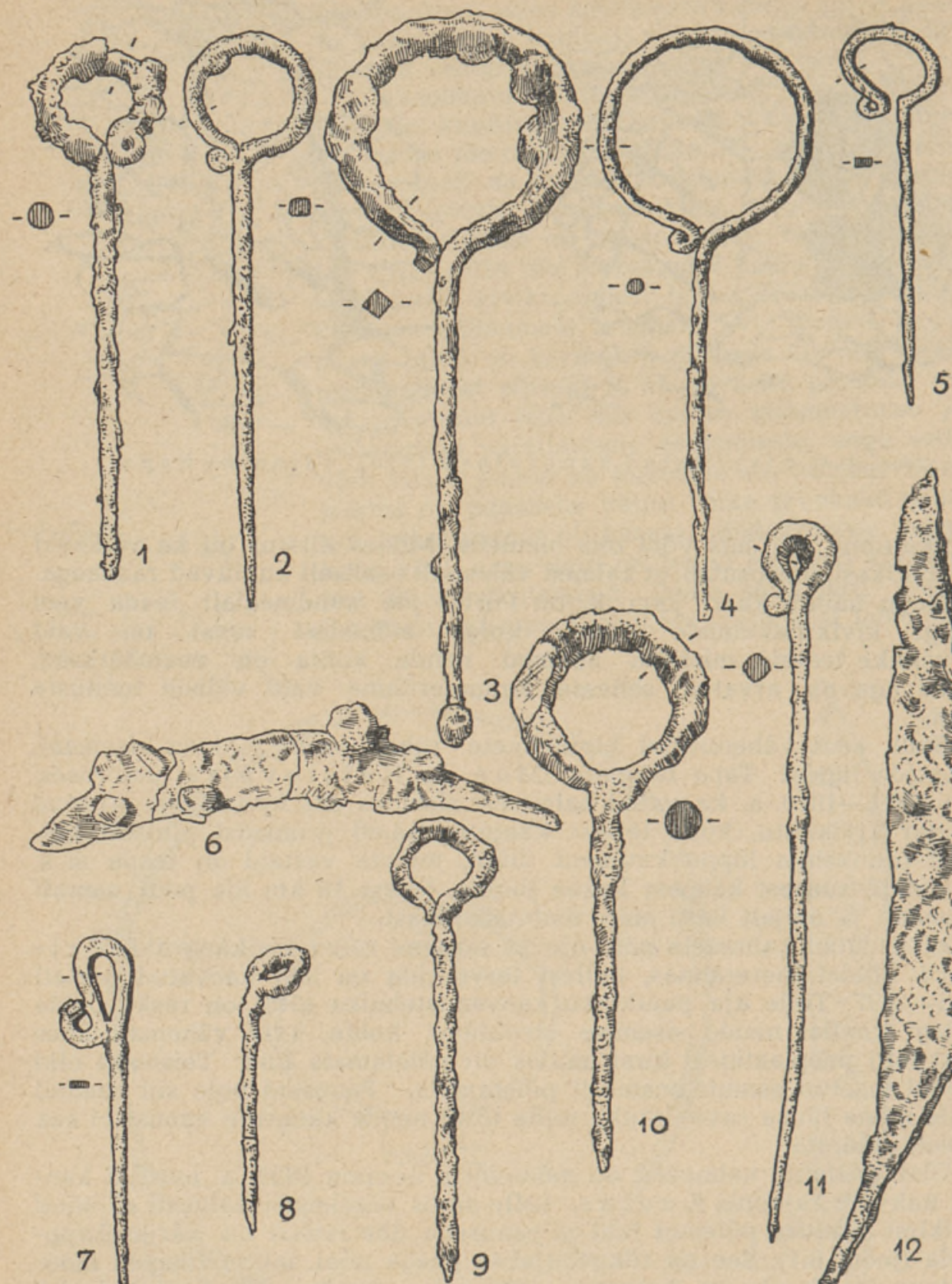

6
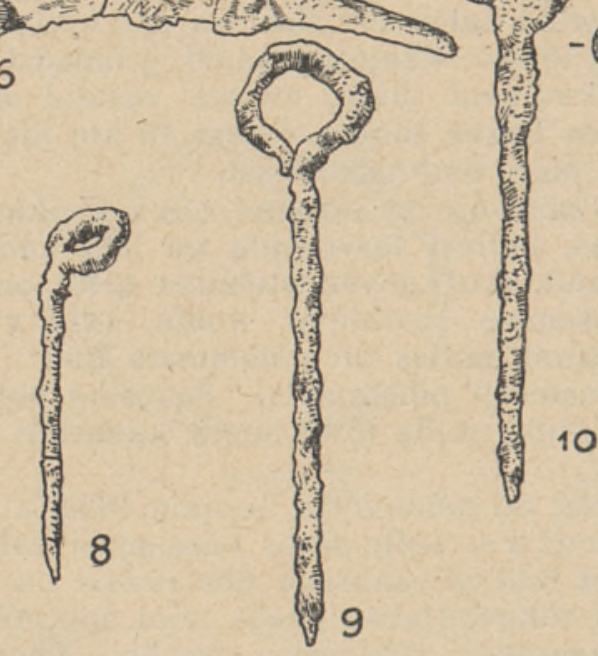

Joon. 6. Varaseima $\mathrm{rauaaj}$ a $\mathrm{t}$ ü $\mathrm{üi}$ i is i leide: 1. Nōel Kuura kivikirstkaImest (AI 3404:5). 2-7. Nõelu ja nuga Toila tarandkalmistust (AI 3952:187, 377, 379 , $171,533,159)$. 8-12. Nõelu ja nuga Elva rajooni Tamsa maa-alusest kalmest AI $3669: 21,30,7,24,22)$. Kōik rauast. Umb. 2/3 loumulikust suurusest.

Karjasekeppnõelu on leitud mujaltki Eestist kivikirst- või neile sarnaseist kalmetest, näit. Harju rajoonis Rannamõisas ja vähe lihtsamal 
kujul ühest kangrust Loksa rajoonis Uuris, Kuusalu lähedal ${ }^{4}$; samuti leiti üks pronksist eksemplar kivikirstkalmest Kõpu poolsaarel Hiiumaals. Nagu allpool selgub, seovad panustest just need nõelad kivikirstkalmeid hilisemate, hoopis teist tüüpi kalmetega, nn. ta randkalmet e ga. Tarandkalmeiks nimetatakse teatavaid Eestis ja Põhja-Lätis esinevaid kivikalmeid, mis koosnevad ühest või sagedasti ka mitmest üksteise külge ehitatud nelinurksest, madala kivitaraga piiratud osast, tarandist. Igasse tarandisse on maetud mitu või koguni terve hulk surnuid. Esineb nii surnute põletamist kui laibamatmist. Sealjuures on surnud maetud üksteise peale, nähtavasti ilma et oleks püütudki üksikuid haudu lahus hoida. Seepärast on tarandites leitavad luud enamasti täitsa segamini. Kirde-Eesti rannikualal on need kalmed mõnikord õige suured, sisaldades kuni kümmekond ritta asetatud tarandit, mis annab neile lääne-ida suunas pikliku kuju, ulatusega kuni mitukümmend meetrit.

Niisuguseks tarandkalmistuks on ka juba ülalmainitud 1947. a. kaevatud kalme Jõhvi rajoonis Toilas (joon. 7). See asub Toila nüüdse surnuaia kõrval, Pühajõe oru vasaku kalda ligidal. Sõja ajal oli see kalme tublisti kannatanud; kaevikutega paljastatud kultuurkihi varisemise oht põhjustaski selle uurimise alla võtmist. Selles kalmes võis eraldada keskmist, kõige vanemat ja ühtlasi kõige monumentaalsemat tarandit (IV), millest oli hästi säilinud ida- ja põhjapoolne müür, laotud suurtest raudkividest. Läänepoolne kalmeosa oli kahjuks kaevikute läbi lõhutud. Ida poolt oli algsele tarandile järk-järgult juurde ehitatud 3 tarandit, neist kõige lähem (III) samuti raudkividest müüriga, teised (II ja I) kitsaste paekividest laotud müüridega.

Keskmised tarandid III ja IV olid täidetud alumises osas raudkividega, mille peal oli Põhja-Eesti kalmetele tavaline paeklibu-mullasegune kord, kuna tarandis I ja II viimane ulatus põhjani. Selles kalmes võis eraldada mitut matmisviisi ja matmiskihti. Pealmine kiht oli õige must, sisaldades sütt ja põlenud luid (vt. profiili joon. $7_{\text {; }}$ profiilis vasakul nähtav pealmine liivakord oli kalmele ilmselt sõjaaegse kaeviku põhjast peale visatud). Selles leidus peamiselt VII-XI sajandi esemeid. Selle musta kihi all, s. o. raudkivide ja neid katvate alumiste paekivide peal ja vahel oli tunduvalt heledam kiht laibamatuste jäänustega. Surnuid oli siia maetud üsna rohkesti, pealistikku, nii et luud olid harilikult võrdlemisi segamini ja murenenud. Seepärast läks korda eraldada ainult mõned üksikud luustikud. Nende suund oli enamasti põhjast lõunasse, kusjuures pea võis asetseda kas põhjas või lõunas. Uhes kohas (luustik D) olid luustikul põlved könksus. Paaril korral (luustikkude B, C ja E juures) võis märgata, et luustike ümber oli laotud längus paeplaate või põllukive, nagu mingi mälestusena kivikirstust; otse kirstudeks neid kive nimetada ei saa. Panuseid võis kindlaks teha vaid ühel luusti,kul (B). Need olid sirbikujuline rauast nuga (joon. 6:6) ja teise suurema raudnoa katkend. Uhes kohas, nimelt luustiku E-F all, seega kolmanda kihina, oli jällegi põletuskiht hulga põlenud luudega. See meenutas vastavat nähtust ühes Napa kivikirstkalmes (vt. ülal).

Jättes kõrvale pealmise kihi VII-XI sajandi leidudega, olid vanemasse aega kuuluvates kihtides peale savinõutükkide ja nugade domineerivateks leidudeks mitmesugust tüüpi karjasekeppnõelad (joon. 6:2 5,7 ), milledest mõned väga meenutavad Kuura ja teistest kivikirstkalmetest leitud eksemplare. Kuna II sajandist alates esineb Kirde-Eesti ala kalmetes juba väga tüüpiline teistlaadi leiumaterjal (silmiksõled, nupp-

\footnotetext{
4 AM (ENSV TA Ajaloomuuseum) 264:1-2 ja AI 3805:41, 53.

5 AI 3909:11.
} 


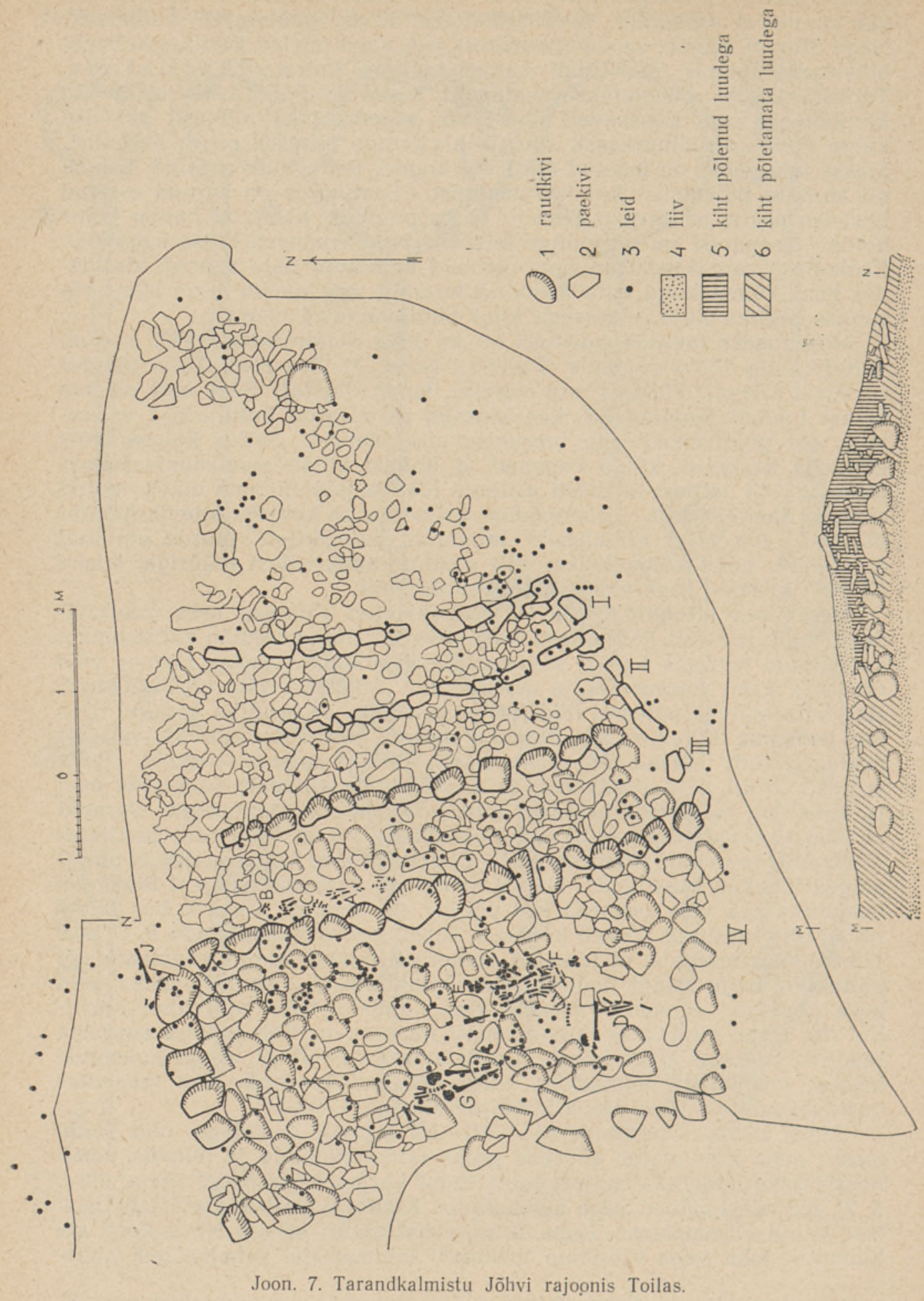


otstega käevõrud, lamedad kitsad käevõrud jm.), mida Toila kalmest pole leitud, siis me vist ei eksi, kui dateerime Toila kalme mõnevõrra varasemasse aega, nimelt peamiselt. I sajandisse m. a. j., kuigi pole muidugi võimatu, et siia on maetud üksikuid surnuid ka veel järgnevate sajandite jooksul. Peale selle on aga kalme uuesti võetud intensiivsemale kasutamisele VII-VIII sajandil m. a. j.

Toila kalmes tuli nähtavale veel üks huvitav asjaolu. Nimelt leidus siin peale kivide vahele maetud luustikkude, nagu neid tavaliselt kohtame tarandkalmeis, põletamata inimluude jäänuseid ka veel kivide all, kalmealusesse liivasesse pinnasesse maetult. Kõige paremini oli neist säilinud ühe luustiku jäänus keskmise tarandi kirdepoolse nurga juures (luustik J), kuna mujal liiva sees leidus vaid üksikuid luid. Samast alumisest liivakihist leiti ka mõned savinõutükid, muuseas kammornamendile sarnlevate ilustustega. Seega võime siin konstateerida matmist maa-alustesse haudadesse, mis oli aset leidnud veel enne tarandkalme ehitamist.

Meil on juba varemalt esinenud üksikuid nähtusi, mis vihjavad maa-aluste kalmete olemasolule meie ajaarvamise alguse ümber. Nii näiteks on Lääne-Eestist ja saartelt, samuti ka Läti NSV ja Leedu NSV aladelt kruusaaukudest korduvalt leitud sellesse aega kuuluvaid oimuehteid koos inimluudega, ilma väliste tundemärkideta haudadest, samuti varane karjasekeppnõel Raplast, mis vastab Toila omadele.

Kuid peale Toila kalme uurimise on ka veel mõned teised viimastel aastatel toimetatud kaevamised tõestanud maa-aluse matmise esinemist meie ajaarvamise alguses. 1945,-1946. aastal toimetatud kivikalme kaevamistel Jõgeva rajoonis Naval leiti kivide ja kultuurkihi alt liivast mõnede laibamatuste jäänuseid. Kalme serva juures asetus teineteise peal vastakates suundades 2 luustikku, mis olid pealt kaetud väikese pikliku kivilasuga. Uhel luustikul oli kaasas rauast karjasekeppnõel ". Teine, pronksist samasugune nõel leiti umbes kalme keskelt, kivide alt, liiva seest, põletamata luujäänuste kõrvalt. Peale selle oli selles kividealuses kihis veel üksikuid põletamata luude jäänuseid. Pealmine, kalmekivide vahel olev kultuurkiht sisaldas põlenud luid ja peale mõne muu varase raudeseme (õõskirves, nuga) veel 3 karjasekeppnõela. Seega näeme, et siingi ei võinud ajaline vahe alumiste laibamatuste ja pealmiste põletusmatuste vahel suur olla.

Seoses nende leidudega tuleb aga veel nimetada üht 1937. a. Elva rajoonis, Tamsa koolimaja õues avastatud leidu, mis koosnes mõnedest rauast karjasekeppnõeltest. Seal toimetatud järelkaevamistel selgus, et siin on tegemist kollektiivse maa-aluse laibakalmistuga, kusjuures leidude hulgas saadi üle kahekümne raudnõela või nõelakatkendi. ${ }^{8}$ Enamasti olid need rõngaspeaga nõelad (joon. 6:8-11), nende hulgas oli ka kaks kõrvale painutatud peaga eksemplari (joon. 6:8), mis oma kuju poolest jätavad üsna varaste nõelte mulje. Peale selle oli leius veel sirbikujuline nuga (joon. 6:12), samuti I sajandi tüüpi, ja lihtne pronksist käevõru.

Ka ühest Jäbara kalmest (C), mis sisaldas läänepoolses osas paar kivikirsthauda ja idapoolses rea tarandeid peamiselt II-III sajandi panustega, leiti tarandi müüri juurest väljaspool tarandit kultuurkihi alt aluspõhjaks oleva kruusa seest kahe täiskasvanu ja ühe lapse luustiku jäänused. Esimestest näis ühel kaasas olevat tulekivikild, teisel oli sirbi-

\footnotetext{
(6I 3968:6.

7 AI 3968:185.

8 AI 3669:1-33.
} 
taoline nuga ${ }^{9}$, mis on samavanune Toila ja Tamsa kalmetest leitud vastavate riistadega.

Detailne kivikirstkalmete ja tarandkalmete ehituse uurimine on näidanud, et need kaks kalmetüüpi on omavahel geneetilises seoses, kuna aga äärmiselt kehva, nagu me nägime, kivikirstkalmete hauainventari ja mitmekesiste II-V sajandi tarandkalmete panuste vahel kaua ei saanud kindlaks teha otsest sidet. Ulalkäsitletud Toila tarandkalme, mis tohiks kuuluda peamiselt I sajandisse m. a. j., täidabki seda lünka, sisaldades uue matmisvormi juures veel esemeid, mis esinevad ka hilistes kivikirstkalmetes.

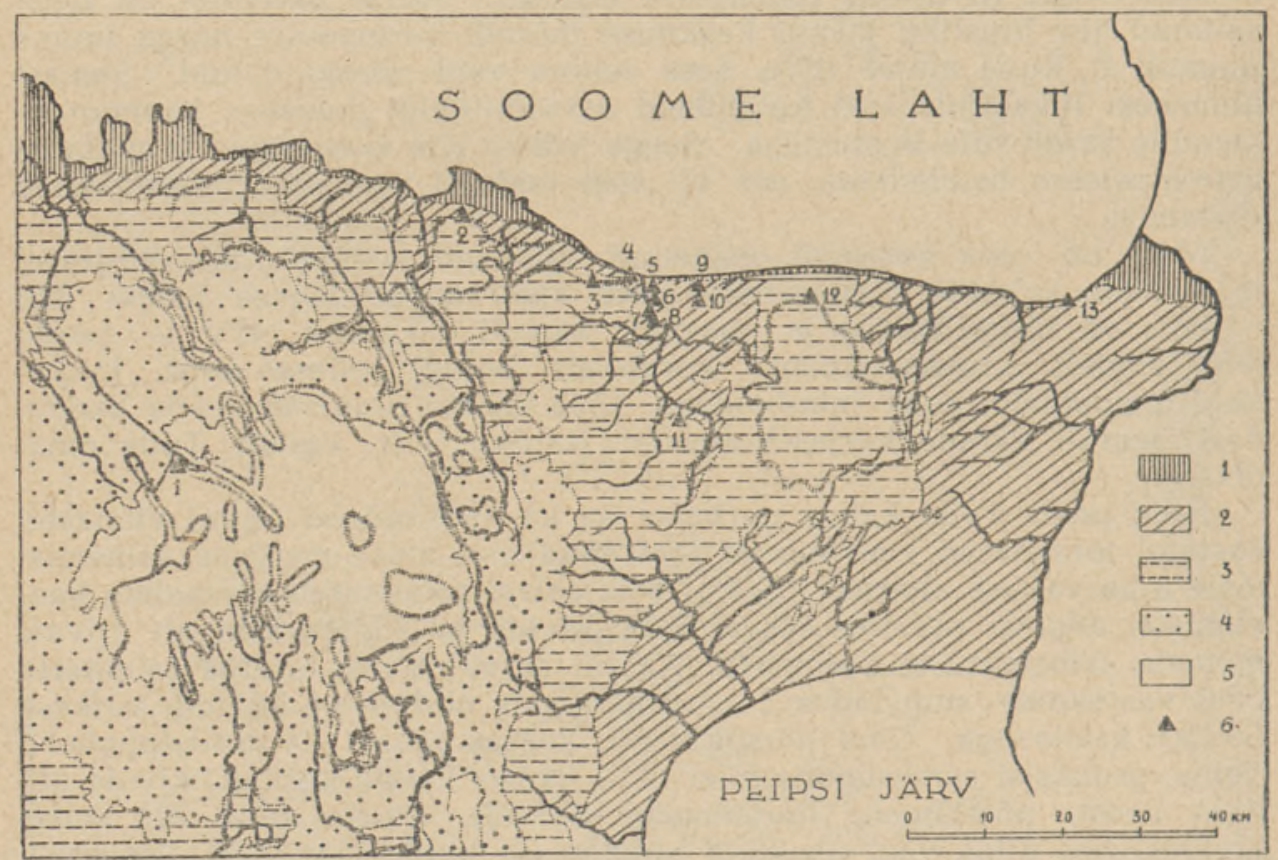

Joon. 8. Kivikirstkalmete. levik Kirde-Eestis (a. 500 e. m. a. $100 \mathrm{~m}$. a. j.) Märgid: 1. Kōrgus $0-20 \mathrm{~m}$ üle merepinna. 2. $20-50 \mathrm{~m}$ ü. m. $3.50-75 \mathrm{~m}$ ü. m. 4. $75-100 \mathrm{~m}$ ü. m. 5. Ole $100 \mathrm{~m}$ ü. m. 6. Kivikirstkalmed. Leiukohad: 1. Moe. 2. Kuura. 3. Rannaküla. 4. Liimala. 5-6. Purtse. 7. Napa. 8. Lüganuse. 9. Jäbara. 10. Varja. 11. Rebu. 12. Järve. 13. Vaivara.

Iseloomulikkudeks panusteks sellel varasel, peamiselt I sajandisse m. a. j. kuuluval tarandkalmete astmel on rauast, harvemini pronksist, karjasekeppnõelad ja tööriistadest kumera seljaga sirbitaolised noad (joon. 6:6, 12), mida võidi kõige ennemini kasutada põõsastelt ja puudelt peente okste lõikamiseks kariloomade toiduks. Ei ole kahtlust, et need valmistamise tehnika ja metalli hulga poolest vähenõudlikud esemed on tehtud kohalikust soorauast. Pronksist - mida vahetuse teel tuli hankida kaugematelt aladelt - leiame nende raudesemete kõrval peale mõne nõela vaid mõnikord veel lihtsaid käevõrusid, nagu näiteks Tamsa leius. Tootmisriistade hulgas näeme nüüd ka juba rauast kirveid. See on kõik kokku täiesti kindlailmeline kalmeinventar, mida võiks senisest palju rohkem arvestada I sajandi materiaalse kultuuri iseloomustamiseks. Alles II sajandil ilmuvad tarandkalmetes esimesed pronk-

- AI 2617:162,204. 
sist sõled (silmiksõled) ja kaunis järsku suureneb ning mitmekesistub siis ka nende kalmete inventar mitmesuguste muude pronksist ehete näol (käevõrud, sõrmused, kaelavõrud jm.), kuna sellest ajast peale kuni I aastatuhande keskpaigani tööriistu ja seega raudesemeid, peale nugade, peaaegu üldse enam hauda kaasa ei panda.

Kaart joon. 8 näitab peamiselt I aastatuhande e, m. a. teise poole kivikirstkalmete levikut Kirde-Eestis, pakkudes väga iseloomustavat pilti: asustatud on eeskätt jõeorgude kaldad jõgede alamjooksul, kus org muutub harilikult laiemaks, ja lavatasandiku merepoolne serv neis kohtades, kus kallas laskub mere poole libamisi või laiade terrassidena, kuna kõrged järskkallaste servad (nagu näiteks Ontikal), samuti veelahkmed ja kaugemad sisemaa alad olid peale mõne üksiku erandi alles asustamata. Tuleb võtta arvesse, et need viimatimainitud alad olid tol ajal alles-põlismetsade all, mis katsid mitte ainult parema pinnasega alasid, vaid ka tänapäeva loopealseid, mis just tänu inimese tegevusele ongi niisugusteks kujunenud. Jõeorud, mõnikord üleujutatavad suurvee ajal, ja libamisi või terrassidena laskuv merekallas olid ainsateks kohtadeks, kus ei olnud tihedat metsa, vaid pigemini võsastik, ja kus oli ka rohumaid - loomulikke karjamaid. Nende alade elanikes, kes matsid oma surnuid kivikirstkalmetesse, tulebki näha karjapidajaid, kes elasid koos sugukondlike kogukondadena. Loomulike karjamaade eelistamine asumiskohtadena selgub siis, kui jälgida üksikult igat tolle aja asustusrühma. Nii näeme, et suhteliselt kõige tihedamini on asustatud Purtse jõe oru mõlemad kaldad. Vastandina puuduvad kivikirstkalmed näiteks Kunda jõel. Looduslike olude erinevus on siin selge: Purtse jõel on lai org libamisi tõusvate kallastega, kuna Kunda jõgi oma alamjooksul läbib paekallast sügava, järskude kallastega oru näol.

Kõneall oleva ajajärgu muistised näitavad, et asustus oli siis juba paikne. See ei võinudki olla teisiti karjandusele rajatud majanduse juures, mis nõudis loomadele talveks toidu varumist. See kajastub ka kalmetes. Need omasid oma sümboolse ehitusega (näit. kiviringid nende ümber) pühapaiga tähendust, mida ei saa omistada oma matusekohtadele mittepaikselt elavad kogukonnad.

Eespool on juba märgitud, et kivikirstkalmed esinevad harilikult mitmekaupa rühmades. Nähtavasti on siin tegemist kalmistutega, mis kuulusid teatavatele patriarhaalsetele suurperedele, kusjuures võib arvata, et iga üksik kangur, sisaldades $10-15$ pikema aja jooksul maetud laiba jäänuseid, oli mõne selle suurperesse kuuluva haru matusepaigaks. Kohtadel aga, kus kangrud katavad laialdasemaid alasid, nagu näiteks Tapa rajoonis Moe-Naistevälja juures või Kuusalu ligidal Kahala järve ümbruses, elas nähtavasti koos rida suurperesid, kes võib-olla kuulusid koguni eri sugukondadesse. Viimane on tõenäoline just ala kohta Kahala järve ümber, kus kalmed rühmituvad mitmesse suuremasse rühma. See järv ühes teda ümbritseva avara madalikuga pakkus nähtavasti elamisvõimalusi suurematele kollektiividele kui suhteliselt kitsad Kirde-Eesti rannikuala jõeorud. Viimastest võib oletada mitmesse sugukonda kuuluvaid asumisalasid ainult Purtse jõe suudmealal. Ei tohi aga muidugi unustada, et tänapäevani säilinud kivikirstkalmed asuvad enamasti põldudel, kus hilisem põllukultuur neid aja jooksul kindlasti palju on hävitanud.

Karjakasvatuse kõrval oli alates II aastatuhandest e. m. a. mõnevõrra tuntud viljakasvataminegi, millest annavad tunnistust paar pronksist sirpi. Saaremaalt, Asva linnuselt, mis kuulub peamiselt I aastatuhande keskele ja teise poolde e. m. a., on leitud linatöötlemise riistu ja ühel sealtsamast saadud savinõukillul on näha nisutera jälg. See- 
pärast ei ole kahtlust, et viljakasvatust harrastati ka kivikirstkalmete ajal, kuigi see karjakasvatuse kõrval alles mõnevõrra varju jäi.

Eesti NSV suhteliselt kehva mullastikuga metsasel alal oli primitiivne viljakasvatus mõeldav eeskätt aleteo näol. Aletegu on uurijate poolt iseloomustatud kui väga suurt tööd nõudvat elatumisviisi ${ }^{10}$. On välja arvestatud, et näiteks 1 tiinu ale ülestöötamine nõudis kuni 90 tööpäeva. See on töö, millega suutis toime tulla vaid paari- või mõnekümneliikmeline kollektiiv. Selliseks kollektiiviks on nähtavasti endiselt patriarhaalne suurpere, kuid selle olulise vahega, et suurpered hakkavad nüüd eristuma üksteisest, asuma laiali uute maade otsingutel.

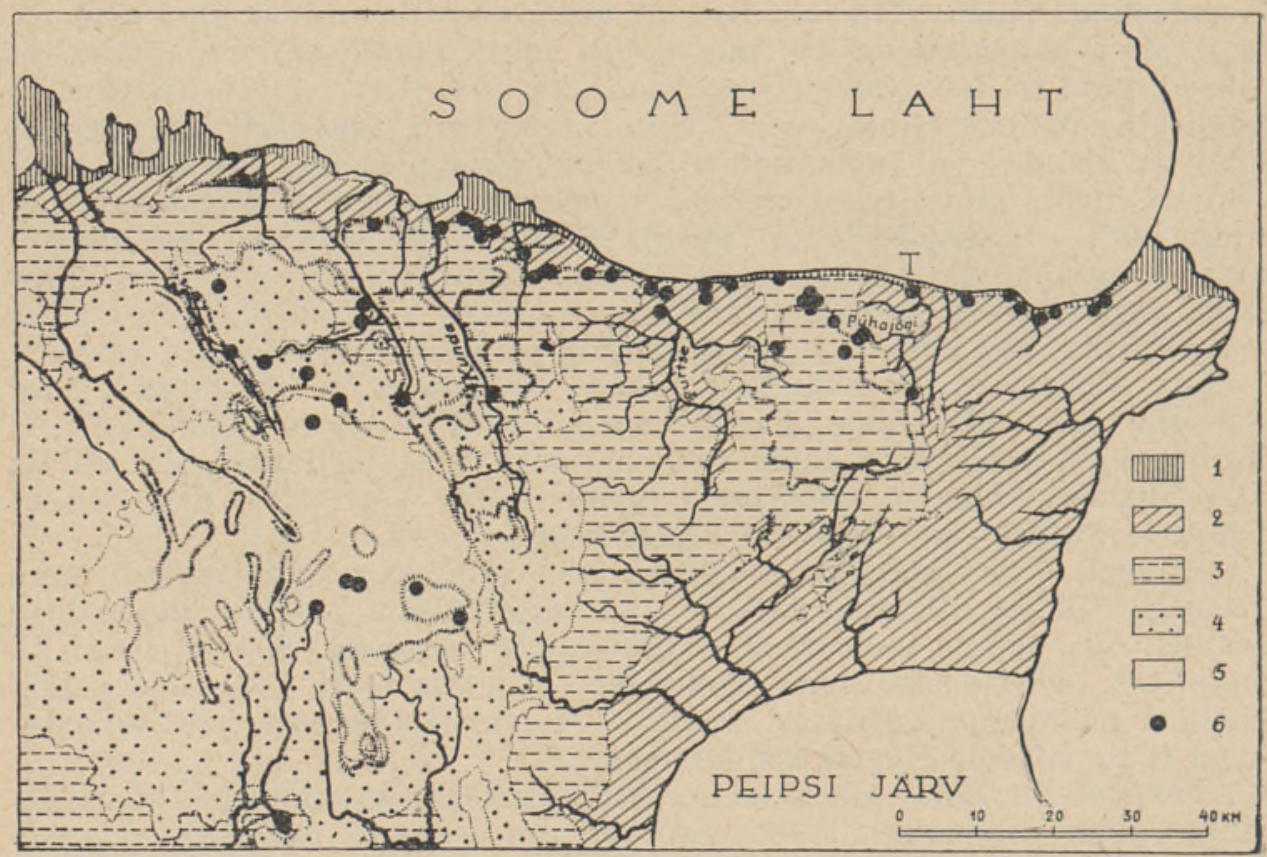

Joon. 9. Tarandka $1 \mathrm{mete}$ levik Kirde-Eestis (a. $100-450$ m.a.j.). Märgid: 1-5. Kõrgused nagu eelmisel joonisel. 6. Tarandkalme.

Uus arenemisaste ilmneb uues kalmetüübis. Nagu me ülal nägime, tekivad I sajandi jooksul suuremate kivikirstkangrutest koosnevate kalmistute asemele üksteisest lahus asetsevad (või ainult kahe-kolme kaupa koondunud) tarandkalmed. Need kollektiivsed matusepaigad, milledesse on maetud ühisel alusel, ilma üksikhaudade eraldamiseta enamasti vähemalt mitukümmend surnut, vastavad oma iseloomult just säärastele suurperedele, mida prof. P. N. Tretjakov peab etnograafiliste paralleelide najal kõige tüüpilisemaks ühiskondlikuks kooseluvormiks aleteo juures $^{11}$. Tarandkalmete üksikud tarandid tohiksid vastata suurperesse kuulunud üksikperedele, kusjuures need on aga tihedalt seotud ühise kalmega, nagu nad olid elus seotud kollektiivse tootmise ja kollektiivse tarbimisega.

10 П. Н. Т реть я ко в, Подсечное земледелие в восточной Европе. Известия Государственной Академии истории материальной культуры XIV:I. Л., 1932, 1k. 9-12. lk. 49 .

Б. Д. Г ре ков, Крестьяне на Руси с древнейших времен до XVII века. М.-Л., 1946,

11 П. Н. Т ре т в я ко в, osund. teos, lk. $4-5$. 
Milliseid laiemaid võimalusi pakkus uus elatumisviis endisega võrreldes looduse poolt antud võimaluste ärakasutamiseks, näitab II-V sajandi tarandkalmete levikus väljenduv asustusepilt (joon. 9), kui võrrelda seda eelmise ajajärgu omaga (joon. 8). Kõigepealt on tootmise areng soodustanud märgatavat asustuse tihenemist. Seejuures pole see aga enam jõeorgude või teiste sisevetega nii seotud nagu varemini. Nii on näiteks täiesti maha jäetud Vaivara rannik, kus ei ole viljakaid maid. Näib, et Purtse jõe piirkonnas on asustus jäänud mõnevõrra harvemaks, kuna seevastu Kunda lähedale on tekkinud mitu panusterikast kalmet. On selge, et nüüd ei ole enam määravad ainult karjakasvatusele soodsad kohad, vaid eeskätt need, mis sobivad viljakasvatuseks, kuna karjakas-

- vatus etendas nüüd juba kõrvalist osa. Merekaldalt ja jõgede piirkondadest on asustus nihkunud jõgedevahelistele veelahkmetele, koondudes tiheda reana Kirde-Eesti põhjapoolsele kõrgemale ja hea mullastikuga moreenalale, eriti panga serva lähedale. Kuid asustus on laienenud ka tublisti lõuna poole, kuhu on tekkinud uusi asustuskeskusi, nagu näit. viljakatele moreenaladele Rakvere ja Väike-Maarja - Simuna ümbruskonnas. Ala Peipsi põhjarannikul, kus sood vahelduvad liivikutega, on aga endiselt asustamata. Huvitaval kombel on siiski asustamata ka need rannikualad, kus kallas on eriti kõrge ja järsk. See torkab silma kõigepealt Ontika ümbruskonnas, kus panga serv on asustamata, kuna kalmed tiheda rühmana hoiduvad lõuna poole, Jõhvi-Kohtla-Järve vahelisele alale. Peale taimestiku võis mõningal määral osa mängida ka raske juurdepääs merele, mis oli tähtis kalastuse, hiljem ka merekaubitsemise seisukohalt. Kohtla-Järve, Kukruse ja Jõhvi vaheline kõrglava omab seevastu Kirde-Eesti kohta head mullastikku. Siia koondunud kalmed on peale mõne üksiku siiski suhteliselt hilisest ajast pärit, olles rajatud peamiselt alles III-IV sajandil. Sealsel heal maapinnal kasvas ka kõige kõrgem ja tihedam mets, mille aleks tegemine oli võimalik alles tootmise teataval arenguastmel.

Kus aga juba kivikirstkalmete ajal asustuse alla võetud pinnas võimaldas ka viljakasvatamist, seal asustus püsis. Eriti iseloomulikud on selles mõttes Jäbara kalmed, mille leiud algavad, nagu eespool nägime, 500 a. paigu e. m. a. ja millest hilisemad seni teada olevad leiud ulatuvad VI sajandisse m. a.j. See on üheks parimaks tõendiks asustuse paiksusest Kirde-Eestis, kus looduslikud olud seda võimaldasid. Hoopis teist pilti näeme näiteks mõnes teises kohas Eestis, kus need maa-alad, mis olid kohased ainult karjakasvatusele, jäid viljakasvatuse peaelatumisviisiks saamisega asustuselt veel kaua hõredaks; niisugused alad olid näiteks meie saared, suurem osa Lääne-Eestit, mõned osad Põhja-Eestist (juba ülalnimetatud kivikirstkalmete levikuala Kuusalus, Kahala järve ümbruskonnas) jt.

Nagu me eespool nägime, hakkab Kirde-Eestis üleminek karjapidamiselt viljakasvatusele kui põhilisele elatumisviisile peegelduma arheoloogilistes mälestusmärkides, ja nimelt kalmetes, alates meie ajaarvamise I sajandist. Kuid J. V. Stalin on oma geniaalses töös "Marksism ja keeleteaduse küsimused" näidanud, et muudatused tootmises ei peegeldu otsekohe pealisehituses. "Pealisehitus ei ole vahetult seotud tootmisega, inimese tootmistegevusega. Ta on seotud tootmisega ainult kaudselt, majanduse vahendusel, baasi vahendusel. Sellepärast ei peegelda pealisehitus muudatusi tootlike jõudude arenemise tasemes otsekohe ega otseselt, vaid pärast muudatusi baasis, tootmises toimunud muudatuste kajastumise kaudu baasis toimuvates muudatustes" ${ }^{12}$. Kui

12 J. Stalin, Marksism ja keeleteaduse küsimused. Tallinn 1951, lk. 8 
nüüd lisaks võtta arvesse, et usundiga seotud nähtused on teiste pealisehituslikkude nähtuste hulgas veel eriti konservatiivsed, siis on selge, et viljakasvatuse kujunemine majanduse aluseks pidi Kirde-Eestis leidma aset märksa varemini, kui see tuleb nähtavale kalmetes. Me vist ei eksi, kui arvame, et see muudatus oli oluliselt toimunud juba I aastatuhande lõpul e. m. a. Sellega sobib hästi ka linnuste uurimise tulemusena ilmnenud fakt, et meie ajaarvamise alguse ümber kasutati KirdeEestis elamiseks juba lahtiseid asulaid, nagu see on iseloomustav viljakasvatuse teataval arenemisastmel. Mis aga puutub kalmetesse, siis võib arvata, et ka need suurpered, kes olid juba üle läinud viljakasvatusele kui põhilisele elatumisviisile ja asunud kaugemale oma sugukondlikest keskustest, matsid oma surnuid veel mõnda aega endistesse kivikirstkalmetesse. Toila tarandkalme oma hilisemate kivikirstkangrute inventarile alles väga sarnanevate panustega näitab, et see üleminek toimus pikkamööda ja arvatavasti ka Kirde-Eesti piiratud alal mitte kõikide sugukondade juures ühel ajal, vaid mõnes kohas kiiremini, teises aeglasemalt. Teatavaid näpunäiteid selle kohta, kuidas metsa alt maa võitmine viljakasvatuse jaoks tegelikult võis sündida, annavad need maaalused hauad, mida eelpool konstateeriti mitme tarandkalme all (Toila, Jäbara). Need kollektiivid, kellele need hauad on kuulunud, olid ilmselt alles nõrgad ja väikearvulised. Tuleb arvata, et siin ongi tegemist esimeste vastavaisse kohtadesse siirdunud asukatega. Et nende töö kandis vilja ja need kollektiivid kasvasid, seda näitavad pärast samale kohale tekkinud suured tarandkalmed.

Kivikirstkalmete kasin inventar näitab, et materiaalne kultuur oli I aastatuhande teisel poolel e. m. a. alles suhteliselt madalal astmel, ja ka läbikäimine naaberkogukondadega oli alles nõrk, sest karjakasvatus ei andnud sellel arenemisastmel veel kuigi suuri produktide ülejääke, mida oleks võinud vahetada muude ainete vastu. Seepärast esineb kivikirstkalmetes näiteks ka väga vähe pronksist esemeid, sest pronksi võisid Eesti territooriumi elanikud saada ainult hõimudevahelise vahetuse teel kaugematelt aladelt.

Kui aga viljakasvatus meie ajaarvamise alguseks muutus põhiliseks elatuse hankimise viisiks ning endiste luu- ja kiviriistade asemele astusid juba kohalike soomaakide alusel rauast valmistatud hoopis efektiivsemad tööriistad, siis hakkas ka elanike materiaalne kultuur rikastuma ja mitmekesistuma. Toila kalme, millele 1951. a. tuli lisaks samalaadne kalme Aseris, on oma lihtsa, vähenõudliku inventariga alles tihedalt seotud kivikirstkalmetega, kuid oma tarandilise struktuuri tõttu juba IIV sajandi tüüpiliste tarandkalmetega. Seega kajastab just see kalme konkreetselt neid muudatusi, mis on toimunud tootmises Kirde-Eesti alal I aastatuhande lõpul e. m. a. ja üleminekut ühest ühiskondlik-majandusliku arengu faasist teise. Arvesse võttes kalmete muutustes peegelduvate pealisehituslike nähtuste mahajäämist tootmisest ja baasist, võib arvata, et viljakasvatus aleteo näol, mille kõrval võib olla ka juba püsivamaid põlde, oli saavutanud oma täie arengu Kirde-Eesti alal hiljemalt I-II sajandi jooksul.

Viljakasvatus, võimaldades ära kasutada laiemaid maa-alasid kui eelmise ajajärgu primitiivne karjakasvatus, süvendas ja kiirendas juba varemini alanud sugukondlike suhete lagunemise protsessi ja kutsus esile märgatava materiaalse kultuuri tõusu, nagu see peegeldub II-V sajandi tarandkalmetes, millede lähem käsitlus ei kuulu enam käesoleva kirjutise raamesse. Siin võib ainult nimetada seda, et nii need II-V sajandi kalmed, kui ka järgnevaisse sajandeisse kuuluvad muistised näita- 
vad katkestamata asustuse ja kultuuri arengut kuni II aastatuhande alguseni, kus eestlaste asumine nüüdsel Eesti territooriumil on juba kindel. See asjaolu lükkab täiesti ümber balti-saksa uurijate sihilikud väited, nagu oleks siin m. a. I aastatuhande jooksul, võinud toimuda etnilisi muudatusi.

Pöördudes tagasi käesolevas kirjutises käsiteldavale üleminekuajale m. a. alguse ümber majanduselt, milles oli ülekaalus karjapidamine, teisele majandusele, kus juhtivat osa mängis viljakasvatus, tuleb nentida, et meil on siin tegemist sisemise arenguprotsessiga, mitte aga, nagu seda väideti kodanlikus arheoloogilises kirjanduses, välistest „kultuurimõjudest" tingitud arenguga. Vastuoksa, alles jõudes ühiskondlik-majandusliku arenemisastmeni, mis võimaldas juba küllalt produktide ülejääki vahetamiseks, hakkasid elavnema suhted teiste hõimudega, eriti kõige lähemate naabrihõimudega - s. o. balti hõimudega lõunas ja slaavi hõimudega idas, kellega põlised tihedad suhted hakkavad, nagu seda näitab uuem uurimine, peegelduma eriti keeles $^{13}$ alates juba viimastest sajanditest enne meie ajaarvamist, s. o. ajast, millest on pärit siin kirjeldatud kivikirstkalmed.

Eesti NSV Teaduste Akadeemia

Ajaloo Instituut

\title{
НАЧАЛО ЖЕЛЕЗНОГО ВЕКА И ПЕРЕХОД К ЗЕМЛЕДЕЛИЮ КАК ОСНОВНОМУ ЗАНЯТИЮ НАСЕЛЕНИЯ В СЕВЕРО-ВОСТОЧНОЙ ЧАСТИ ТЕРРИТОРИИ ЭСТОНИИ
}

\author{
Резюме \\ М. Х. ШМИДЕХЕЛЬМ, \\ кандидат исторических наук
}

Многочисленные археологические памятники северо-восточной части Эстонской ССР позволяют лучше, чем в других частях Эстонии, проследитъ развитие соџиально-экономического строя за время от середины I тысячелетия до нашей әры и до середины I тысячелетия нашей эры. Однако әти памятники изучены неравномерно, так как в буржуазный период исследовались главным образом большие, богатые инвентарем каменные могилы первых веков нашей эры. Как прибалтийско-немеџкие, так и эстонские исследователи буржуазного периода пытались использовать этот материал в своих классовых интересах. Каменные курганы последних веков до нашей әры исследованы поэтому значительно слабее, причем почти неисследованным оставалось переходное между әтими типами погребений время около начала нашей әры.

Разрабатывая этот материал в свете марксистско-ленинского понимания истории, мы приходим к новым выводам, тем более, что раскопки последних лет значительно пополнили его. Следует учесть, что материал этот пока односторонен, так как получен почти исключительно из могил. Произведенные в северо-восточной части Эстонской ССР в 1949-1950 годах раскопки на

${ }^{13}$ P. A riste, Eesti ja vene rahva sõbralikud suhted keeleteaduse valguses. „Rahva Hääl” 1951, nr. 252, lk. 3. 
городище Койла, относящемся к первым векам нашей эры, и в 1951 1952 годах на городище Клооди (III-IV века) не обнаружили остатков укрепленных поселений, но показали, напротив, что население обитало в то время в открытых поселениях.

Памятниками конџа әпохи бронзы и начала железного века (с V века донашей әры по I век нашей әры) являются в Северо-Восточной Әстонии небольшие каменные курганы (рис. $1,4,5)$. Эти курганы встречаются небольшими группами и содержат обычно несколько, а иногда до 10-15 погребений, большей частью в каменных ящиках. Они чрезвычайно бедны инвентарем и только в исключительных случаях содержат предметы, поддающиеся точной датировке. В одном из ящиков кургана в Ябара (рис. 2) были найдены бронзовая шейная гривна типа середины I тысячелетия до нашей эры, бронзовый браслет и большой железный нож (рис. 3). Употребление на территории Эстонии железа в такой ранний период становится вероятным, если учесть открытие М. Е. Фосс на берегу Галичского озера места выплавки железа в VIII-VII веках до нашей әры.

К числу наиболее поздних курганов с каменными ящиками относится курган в Куура, в котором найдена железная булавка с кольџеобразной головкой (рис. 6:1). Такие булавки найдены в каменных курганах с ящиками также и в других частях Эстонии. Подобные же железные булавки с кольџеобразной головкой различных размеров составляют большую часть инвентаря каменной могилы в Тойла, которая по характеру своей конструкџии соответствует уже могилам, типичным для I-V веков нашей эры. Это большие, плоские каменные могилы с погребениями коллективного характера, состоящие из ряда пристроенных друг к другу четырехугольных оградок (рис. 7).

Погребальный инвентарь могилы в Тойла примитивен и однообразен: Фрагменты керамики, вышеназванные булавки с кольџеобразной головкой, серповидные ножи и пр. (рис. $6: 2-7$ ). Здесь еще совершенно отсутствует типичный для могил Северо-Восточной Эстонии инвентарь II столетия. Это позволяет отнести могилу в Тойла к I столетию нашей эры. Особого внимания заслуживают остатки нескольких костяков, найденных глубже каменной кладки и собственно культурного слоя в материковом песке. За последние годы и в некоторых других местах Эстонии обнаружены грунтовые погребения примерно I века нашей әры, содержавшие такие же железные булавки с кольџеобразной головкой (например, находка около 20 булавок с остатками костей в Тамса, к югу от г. Тарту, железных и бронзовых булавок под каменной могилой в Нава, к северу от Тарту и пр.). Таким образом, все эти находки связаны.между собой и представляюг в совокупности весьма однородный комплекс погребального инвентаря I столетия нашей эры, своей примитивностью и единообразием резко отАичающегося от изобилующего формами инвентаря последующих столетий.

В соџиально-экономическом отношении этот период, находяџий свое отражение в характере и инвентаре могил, означает переход населения от хозяйства с известным преобладанием скотоводства к хозяйству, основой 
которого стало земледелие. Карта распространения памятников второй половины I тысячелетия до нашей эры и I века нашей эры (рис. 8) показывает, что население занимало в это время преимушественно только прнбрежную часть Северо-Восточной Эстонии, притом не сплошь, а главным образом края пологих долин рек (особенно возвышенные края широкой долины реки Пурџе) и край глинта в тех местах, где он спускается к морю полого или террасами. Эти пространства, покрытые в то время по преимуществу травянистой и редкой древесной растительностью, были наиболее пригодными для скотоводства, тогда как остальное силурийское плато Северо-Восточной Эстонии было еше сплошь покрыто лесами. Очевидно, мы имеем здесь дело с патриархальными большими семьями, которым принадлежали известные группы каменных курганов, причем единичные курганы принадлежали, повидимому, малым семьям, входяшим в семейную общину. В некоторых же местах, где курганные могильники конџентрируются особенно тесно, обитало, должно быть, несколько больших семей, принадлежащих к одному, а в известных случаях, может быть, и к различным родам.

При переходе населения от скотоводства как ведущей формы хозяйства к земледелию эти большие семьи стали от краев речных долин проникать на плодородные водоразделы. В отличие от курганных могильников, которые сосредоточивались в пригодных для скотоводства местах, могилы с оградками разбросаны большей частью поодиночке, или всего по 2-3 в одном месте. Включая обыкновенно несколько десятков погребений коллективного характера, әти могилы соответствуют скорее всего большесемейным коллективам, которые, как показал П. Н. Третьяков, являются особенно типичными для населения, занимаюџегося подсечным земледелием. Карта распространения могия с каменными оградками во II-V веках нашей эры (рис. 9) показывает, что население стало значительно более плотным. На севере могилы тянутся теперь тесной џепью вдоль глиннта, а в западной части Северо-Восточной Эстонии население проникло значительно южнее чем прежде на плодородные моренные возвышенности в окрестностях Раквере и ВяйкеМаарья. Заселенные же во второй половине I тысячелетия до нашей эры места, которые помимо скотоводства давали возможность также для развития земледелия, остаются заселенными и позже, как, например, окрестность Ябара, где могильники существуют начиная с $\mathrm{V}$ века до нашей эры и до VI века нашей әры. Зато пространство на север и северо-запад от Чудского озера, покрытое песками и болотами, остается попрежнему незаселенным.

Самые ранние могилы с оградками, знаменующие собою переход от скотоводства к земледелию как основной отрасли хозяйства, датируются по могильному инвентарю I веком нашей эры. Однако необходимо иметь в виду положения товарища Сталина о базисе и надстройке, высказанные им в его гениальном труде «Марксизм и вопросы языкознания», согласно которым изменения в производстве отражаются в явлениях надстроечного характера не непосредственно, а только после изменений в базисе. Изменения в могилах, связанные с изменениями культа, - явления надстроечного характера отстают от развития как производства, так и базиса. Из этого вытекает, что 
самый переход от скотоводства к земледелию как основному способу добывания средств к жизни должен был совершиться раньше, чем это находит отражение в характере могил, а именно уже в конџе I тысячелетия до нашей эры. С этим вполне согласуется тот факт, что около начала нашей эры в Северо-Восточной Эстонии уже прекратили свое существование укрепленные поселения.

Преобладание земледелия повлекло за собой значительный подъем материальной культуры и оживление межплеменного обмена. Расселение же больших семей на плодородные земли является новым этапом в разложении родового строя.

Ннститут истории

Академии Наук Эстонской ССР 